\title{
Tissue Factor Pathway Inhibitor Reduces Mortality from Escherichia coli Septic Shock
}

\author{
A. A. Creasey, ${ }^{*}$ A. C. K. Chang, ${ }^{*}$ L. Feigen, ${ }^{5}$ T.-C. Wün," F. B. Taylor, Jr., ${ }^{\star}$ and L. B. Hinshaw \\ ${ }^{*}$ Chiron Corporation, Emeryville, California 94608; ${ }^{\ddagger}$ Oklahoma Medical Research Foundation, Oklahoma City, Oklahoma 73104; \\ ${ }^{\S}$ Searle Pharmaceuticals, Inc., Chicago, Illinois 60077; and "Monsanto Co., Chesterfield, Missouri 63198
}

\begin{abstract}
This study was designed to test the hypothesis that tissue factor pathway inhibitor (TFPI) plays a significant role in vivo in regulating coagulation that results from exposure of blood to tissue factor after vascular injury as in the case of gram negative sepsis. Highly purified recombinant TFPI $(6 \mathrm{mg} / \mathrm{kg})$ was administered either 30 min or $4 \mathrm{~h}$ after the start of a lethal intravenous Escherichia coli infusion in baboons. Early posttreatment of TFPI resulted in ( $a$ ) permanent seven-day survivors $(5 / 5)$ with significant improvement in quality of life, while the mean survival time for the controls $(5 / 5)$ was $39.9 \mathrm{~h}$ (no survivors); and (b) significant attenuations of the coagulation response and various measures of cell injury, with significant reductions in pathology observed in $E$. coli sepsis target organs, including kidneys, adrenals, and lungs. TFPI administration did not affect the reduction in mean systemic arterial pressure, the increases in respiration and heart rate, or temperature changes associated with the bacterial infusion. TFPI treated $E$. coli infected baboons had significantly lower IL-6 levels than their phosphate buffered saline-treated controls, however tumor necrosis factor levels were similarly elevated in both groups. In contrast to the earlier 30-min treatment, the administration of TFPI at $4 \mathrm{~h}$, i.e., $240 \mathrm{~min}$, after the start of bacterial infusion resulted in prolongation of survival time, with $40 \%$ survival rate $(2 / 5)$ and some attenuation of the coagulopathic response, especially in animals in which fibrinogen levels were above $10 \%$ of normal at the time of TFPI administration. Results provide evidence for the significance of tissue factor and tissue factor pathway inhibitor in bacterial sepsis, and suggest a role for blood coagulation in the regulation of the inflammatory response. (J. Clin. Invest. 1993. 91:2850-2860.) Key words: tissue factor pathway inhibitor - coagulation • sepsis • tissue factor $\bullet$ inflammation
\end{abstract}

Address reprint requests to Dr. Abla A. Creasey, Chiron Corporation, 4560 Horton Street, Emeryville, CA 94608.

Received for publication 25 November 1992 and in revised form 8 March 1993.

J. Clin. Invest.

(C) The American Society for Clinical Investigation, Inc. $0021-9738 / 93 / 06 / 2850 / 11 \quad \$ 2.00$

Volume 91, June 1993, 2850-2860

\section{Introduction}

Disseminated intravascular coagulation (DIC $)^{1}$ is a disorder that occurs in response to invading microorganisms and tissue injury characterized by widespread deposition of fibrin in blood vessels. One of the initiating causes of DIC appears to be the inappropriate exposure of the blood to tissue factor (1). During this process, there is consumption of fibrinogen, a reduction in platelet count, and increases in prothrombin and activated partial thromboplastin times. The clinically mild to severe form of DIC is thought to occur with high frequency in septic shock patients as well as in patients with head trauma, burns, obstetric complications, transfusion reactions, and some types of tumors (2).

Vascular endothelial cells and blood monocytes can be induced to synthesize and express tissue factor (TF) in vitro by inflammatory mediators including endotoxin, TNF and IL-1 (3-7). Enhancements of tissue factor expression and activity have also been observed in mononuclear cells from the blood of patients with meningococcemia (8). Infusion of tissue factor into healthy rabbits causes DIC (9). Furthermore, rabbits injected with polyclonal antibody to tissue factor before injection of endotoxin have a substantially reduced incidence of DIC (9). Administration of tissue factor monoclonal antibodies to baboons before challenge with a lethal dose of bacteria attenuated the coagulopathic response and degree of cardiovascular collapse and increased survival (10).

Blood contains a tissue factor pathway inhibitor protein (TFPI) that was reported to inhibit activated Factor $\mathrm{Xa}$ directly and in a Xa-dependent manner and to inhibit VIIa/TF activity by forming a quarternary $\mathrm{Xa} / \mathrm{TFPI}$ /VIIa complex (11). Recently, it has been suggested that at high concentrations, TFPI can inhibit VIIa/TF in the absence of Xa (12). Rabbits immunodepleted of plasma TFPI activity were sensitized to intravascular coagulation induced by the infusion of a concentration of TF that is without effect in rabbits with normal levels of plasma TFPI activity (13). Coinfusion or pretreatment of TFPI with tissue factor into rabbits suppressed the

1. Abbreviations used in this paper: APTT, activated partial thromboplastin time; DEGR-Xa, active-site-inhibited Xa; DIC, disseminated intravascular coagulation; FDP, fibrin-degradation products; IPCFIA, particle concentration fluorescence immunoassay; MSAP, mean systolic arterial pressure; PT, prothrombin tine; TF, tissue factor; TFPI, tissue factor pathway inhibitor. 
tissue factor mediated systemic fibrinogen decrease and fibrin deposition in the lungs (14).

TFPI is synthesized by endothelial cells (15). Recent data from cultured endothelial cells and lung tissue suggest that TFPI may be slightly upregulated during an inflammatory response (16). TFPI levels were determined in patients with postoperative/posttraumatic septicemia (17). In the survivors, initial low TFPI activity was normalized during recovery. In the fatal cases, a progressive increase in TFPI activity was observed until death. This increase may have been caused by the release of TFPI from damaged endothelium.

A recent study (18) reported that TFPI exists in vivo in at least three different pools: associated with lipoproteins (54-142 $\mathrm{ng} / \mathrm{ml})$, sequestered in platelets $(8 \mathrm{ng} / \mathrm{ml})$, and part of which is released into plasma by heparin $(220-800 \mathrm{ng} / \mathrm{ml})$, possibly from the luminal surface of the vascular endothelia. TFPI antigen levels associated with plasma lipoproteins were reported to be decreased in some, but not all, patients with gram negative bacteremia having evidence of DIC. However, this pool of TFPI did not appear to decrease in patients with chronic hepatic failure, warfarin therapy, primary pulmonary hypertension, and thrombosis (18), suggesting that the glycoprotein-associated pool may be more specifically involved in DIC.

In the present study, we examined the therapeutic use of TFPI in a lethal $E$. coli septic shock model to determine if TFPI could inhibit DIC in an acute infection and inflammatory setting, and whether administration of TFPI would lead to reduced mortality resulting from sepsis.

\section{Methods}

Recombinant tissue factor pathway inhibitor. TFPI was expressed in the human hepatoma cell line SK Hep as described (19). The material was purified to provide $>95 \%$ pure preparations. TFPI was formulated in $150 \mathrm{mM} \mathrm{NaCl}$ and $20 \mathrm{mM} \mathrm{NaPO}_{4}(\mathrm{pH} \mathrm{7.2)}$, which served as the excipient control. Final protein concentration in a TFPI sample ranged from $2.3-3.7 \mathrm{mg} / \mathrm{ml}$, determined by amino acid composition; endotoxin levels ranged from 8 to 27 endotoxin units per $15 \mathrm{mg}$ of protein. TFPI lots were monitored for biological activity using a modified prothrombin time assay (19).

Baboons. Male and female Papio anubis baboons $(7.6 \pm 2.4 \mathrm{~kg})$ from the Charles River Primate Center (Wilmington, MA) were quarantined for a minimum of $30 \mathrm{~d}$ in the University of Oklahoma Health Sciences Center Animal Resource Facility (Oklahoma City, OK). Animals were free of infections or parasites. All animals had hematocrit levels $\geq 36 \%$.

Bacteria. Escherichia coli 086:K61H organisms (33985; American Type Culture Collection, Rockville, MD) were isolated from a stool specimen at Children's Memorial Hospital, Oklahoma City. They were stored in the lyophilized state at $4^{\circ} \mathrm{C}$ after growth in tryptic soybean agar and reconstituted and characterized as described (20).

Experimental and infusion procedures. Each baboon was immobilized with ketamine hydrochloride, $14 \mathrm{mg} / \mathrm{kg}$ i.m. on the morning of the study, and slowly anesthetized with sodium pentobarbital $(\sim 9$ $\mathrm{mg} / \mathrm{kg}$ ) via a percutaneous catheter positioned in the cephalic vein as described (21). To compensate for insensible fluid loss, animals were infused with isotonic saline at $3.3 \mathrm{ml} / \mathrm{kg}$ per $\mathrm{h}$ for $12 \mathrm{~h}$ via the brachial vein $30 \mathrm{~min}$ or $240 \mathrm{~min}$, respectively, after the administration of bacteria. TFPI was simultaneously administered at a loading dose of 700 $\mu \mathrm{g} / \mathrm{kg}$ for $15 \mathrm{~min}$, and a continuous infusion of $10 \mu \mathrm{g} / \mathrm{kg}$ per min for an additional $525 \mathrm{~min}$ (counting from the start of the bacterial infusion, which was defined as $T=0$ ). To deliver the same total TFPI dose in all baboons, animals treated at +240 min received simultaneously a loading dose of $2.8 \mathrm{mg} / \mathrm{kg}$ for $15 \mathrm{~min}$ and a continuous infusion of 10 $\mu \mathrm{g} / \mathrm{kg}$ per min for $480 \mathrm{~min}$.
E. coli $086: \mathrm{K} 61 \mathrm{H}$ were used to inoculate tryptic soy broth agar, and viability counts of the inoculum were determined by standard dilution techniques. At time zero, an infusion of live bacteria was started through a percutaneous catheter in the right cephalic vein and continued for $2 \mathrm{~h}$. A total of $\geq 4.5 \times 10^{10}$ organisms were administered (4 $\mathrm{ml} / \mathrm{kg}$ ).

The femoral artery and one femoral vein were cannulated aseptically to measure mean systemic arterial pressure, obtain blood samples, and administer antibiotics. Gentamicin was administered by means of 30 -min. intravenous infusions. $9 \mathrm{mg} / \mathrm{kg}$ were administered at the end of $E$. coli infusion (i.e., at $T+120) .4 .5 \mathrm{mg} / \mathrm{kg}$ was administered at $T$ +360 and again at $T+540 \mathrm{~min}$. Additional Gentamicin $(4.5 \mathrm{mg} / \mathrm{kg}$ i.m.) was then administered at the end of the experiment and once daily for $3 \mathrm{~d}$.

Animals were maintained under anesthesia and monitored continuously for $12 \mathrm{~h}$. Blood samples were collected hourly for hematology, clinical chemistry, cytokines (TNF, IL-6), and TFPI determinations. Similarly, measurements of respiration rate, heart rate, mean systemic arterial pressure, and temperature were collected hourly. Animals were continuously observed for the first $30 \mathrm{~h}$ of the experiment. Those surviving $7 \mathrm{~d}$ were considered permanent survivors and were subsequently killed with sodium pentobarbital for necropsy on the 8th day.

\section{Assays}

Endotoxin measurement. Endotoxin levels in TFPI preparations and the excipient buffer were determined by the Limulus amebocyte lysate test (22). LPS from E. coli (B5505; Mallinckrodt Specialty Chemicals, Chesterfield, MO) were included as a standard. The detection limit of the assay was 10 endotoxin units $(\mathrm{EU}) / \mathrm{ml}$.

TNF ELISA. Baboon TNF levels in plasma were measured using an ELISA developed for detecting human TNF (23): a purified monoclonal anti-TNF antibody (24510E11) was bound to microtiter plate wells (Dynatech Immunolon I; Fisher Scientific Co., Pittsburgh, PA). Unoccupied binding sites on the plastic were then blocked with BSA. Aliquots of standard concentrations of purified recombinant human TNF or baboon plasma samples were incubated in duplicate. ELISA wells were exposed to horseradish peroxidase (HRP)-conjugated affinity packed polyclonal rabbit antibody to recombinant human TNF followed by $O$-phenylenediamine substrate as chromogen. Wells were rinsed repeatedly with PBS, pH 7.5, between successive incubations. $O D$ was read on an automated dual-wavelength plate reader at $490 \mathrm{~nm}$ (Bio-Tek Instruments, Inc., Burlington, VT). The detection limit for baboon TNF in this assay was $0.5 \mathrm{ng} / \mathrm{ml}$.

IL-6 bioassay. IL-6 bioactivity was quantified in baboon plasma using the IL-6-dependent murine hybridoma cell line B9. Commercially available IL-6 (Amgen Biologicals, Thousand Oaks, CA), was used as the assay standard (23). The detection limits of this assay were $10 \mathrm{pg} / \mathrm{ml}$.

TFPI levels. Particle concentration fluorescence immunoassay (PCFIA) was used to measure the concentration of TFPI antigen in plasma. Fluricon ${ }^{\mathrm{TM}}$ 0.7-0.9 $\mu \mathrm{m}$ carboxyl-styrene particles (Idexx Corp., Westbrook, ME) was conjugated with protein A-Sepharose 4B purified rabbit antibody against TFPI according to the manufacturer's procedure. Specific anti-TFPI-Ig was purified from rabbit antiserum by affinity chromatography on a TFPI-Sepharose 4B column and labeled with FITC according to the procedure suggested by Idexx. All the samples and standards were diluted into Tris buffered saline and control plasma (plasma obtained from the same baboon just prior to the injection of TFPI) such that the assay mixture contained $10 \%$ plasma. $40 \mu \mathrm{l}$ of samples were mixed with $20 \mu \mathrm{l}$ of antibody-coated particles in the assay wells and incubated for $1 \mathrm{~h}$ at room temperature. $30 \mu \mathrm{l}$ of FITC labeled anti-TFPI-Ig was then added, and the mixture was incubated for $1 \mathrm{~h}$. Fluorescence was measured on a Fluorescence Concentration Analyzer (Idexx). The concentrations of TFPI in the samples were calculated by comparing with those of the standards.

TFPI activity level in plasma was measured by a modified prothrombin time assay as described previously (19). Reference standards were prepared by supplementing control plasma with purified 
TFPI. Plasma samples were diluted with control plasma to a TFPI level within those of the standards. The concentration of active TFPI in plasma samples were calculated by comparing with the standards.

Pharmacokinetic analysis. The data for each baboon ( $\mu \mathrm{g}$ TFPI $/ \mathrm{ml}$ plasma at various sample times) were fit to a two-compartment model. The model parameters were determined by nonlinear least squares curve-fitting procedures using the PKDAAS data analysis system (developed for the VAX computer at Chiron Corporation). Corrected concentrations at each time, $C(t)$, were weighted as the reciprocals of each concentration squared. The weighted values were then fitted to individual subjects' curves using the following biexponential equation:

$C(t)=(\mathrm{DOSE} / V C)^{*}\left[(1-\mathrm{B}) * 2^{-t / \alpha}+\mathrm{B}^{*} 2^{-t / \beta}\right]$,

where $t$ is time and $V C, \mathrm{~B}, \alpha$, and $\beta$ are model parameters. The sum of the coefficients was normalized to 1.0. The systemic clearance (CL) was then calculated from:

$C L=V C / \mathrm{MRT}$, where

$\operatorname{MRT}=\left[(1-\mathrm{B}) * \alpha+\mathrm{B}^{*} \beta\right] \ln (2)$.

Statistical Analysis. Data were analyzed with the Students' $t$ test to determine significant differences $(P<0.05)$ in means between groups at given times. The ANOVA and the multicomparison Duncan's test were used to determine significant differences between means at time 0 and subsequent times within groups. The Fisher's exact test was used to determine significant differences between groups with respect to survival rates.

\section{Results}

Pharmacokinetic studies. To establish the appropriate TFPI dosing regimen for the $E$. coli septic shock model, we performed a pharmacokinetic study in three healthy baboons. Fig. 1 shows that administered as a bolus at $0.5 \mathrm{mg} / \mathrm{kg}$, TFPI exhibited a two-phase elimination curve; an alpha phase with a halflife of approximately $2 \mathrm{~min}$ and a beta phase with a half-life of about $2 \mathrm{~h}$. The differences in antigenic and functional TFPI levels in the pharmacokinetic experiments are possibly due to the partial degradation of TFPI protein in vivo as previously observed in rabbits (24).

The pharmacokinetic data were then modeled as described in Methods to identify the necessary TFPI dosage to achieve a circulating TFPI serum concentration of $2 \mu \mathrm{g} / \mathrm{ml}$, which was arbitrarily defined as the desired TFPI blood concentration since it has been reported that endogenous levels of TFPI in primates are approximately $0.1 \mu \mathrm{g} / \mathrm{ml}$ (25). Thus to achieve a 20 -fold increase in TFPI serum concentrations in the baboons, we administered TFPI at a loading dose of $700 \mu \mathrm{g} / \mathrm{kg}$ and a maintenance dose of $10 \mu \mathrm{g} / \mathrm{kg}$ per min (i.e., a total dose of $6,000 \mu \mathrm{g} / \mathrm{kg}$ ) started simultaneously, $30 \mathrm{~min}$ after the start of the $E$. coli infusion.

A lethal, 2-h intravenous infusion of $E$. coli was administered to 10 baboons. Table I shows that TFPI rescued five of five $E$. coli-treated baboons who became permanent survivors. The mean $E$. coli dosage of the TFPI treated was $5.7 \times 10^{10}$ $\mathrm{CFU} / \mathrm{kg}$, and all animals survived more than $7 \mathrm{~d}$. The mean $E$. coli dosage of the excipient control group was $5.5 \times 10^{10} \mathrm{CFU} /$ $\mathrm{kg}$ and the mean survival time was $39.9 \mathrm{~h}$ ( Table I). The mean weight of the excipient control group was $8.4 \mathrm{~kg}(5.9-12.1 \mathrm{~kg})$ and that of the TFPI treated was $6.8 \mathrm{~kg}(5.2-8.0 \mathrm{~kg})$. There were two females and three males in the excipient control group, while the TFPI treated group consisted of five males. There was no difference in the mean dose of $E$. coli administered to each group $(P>0.05)$ nor in the animals' weights $(P$ $>0.05$ ).

TFPI-treated baboons moved about the cage energetically, consumed some food, and drank water normally within $24 \mathrm{~h}$ of receiving lethal $E$. coli $\left(\mathrm{LD}_{100}\right)$. The excipient control baboons, however, were very lethargic, appeared to have difficulty breathing, and exhibited multiple petechiae over their bodies indicating the occurrence of DIC in the dermal microvasculature.

Coagulation and hematological responses to TFPI administration at $+30 \mathrm{~min}$. To determine the mechanism by which TFPI protected the $E$. coli infected baboons, we measured se-
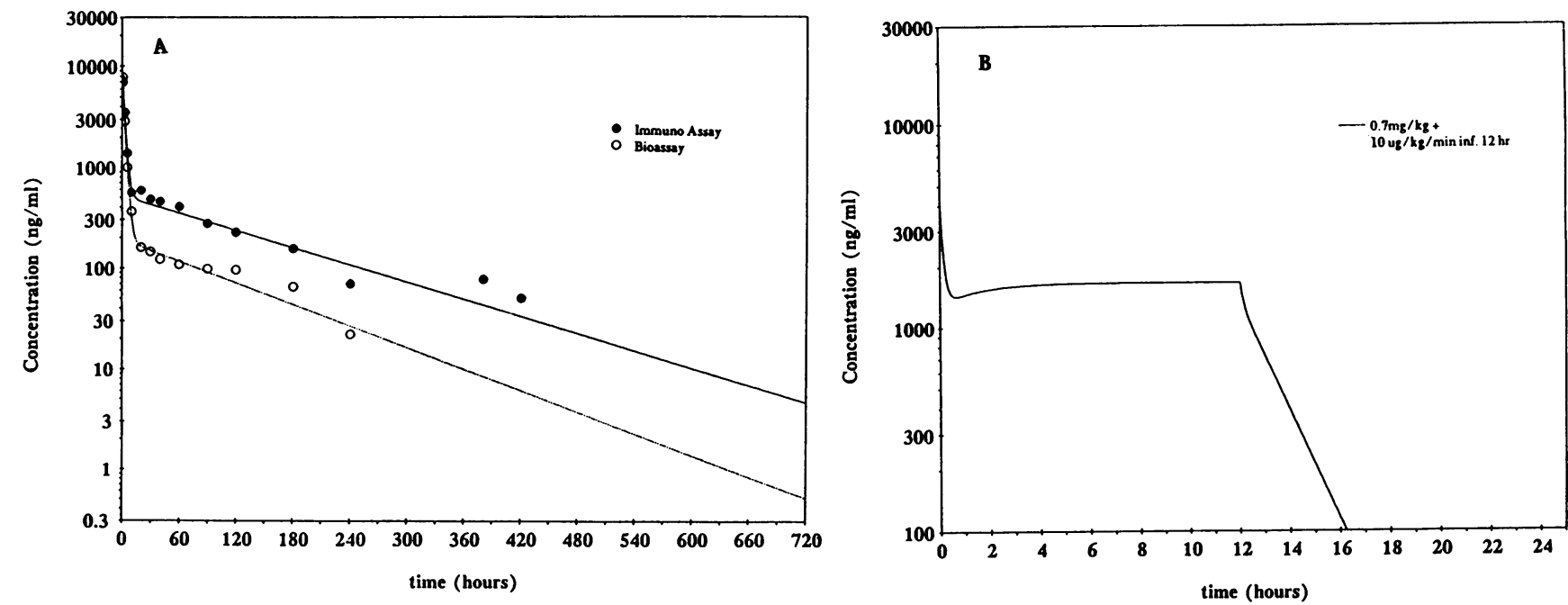

Figure 1. Pharmacokinetic profile of TFPI. (A)TFPI (at $0.5 \mathrm{mg} / \mathrm{kg}$ ) was given as an intravenous bolus over $30 \mathrm{~s}$ to two healthy baboons. Blood was sampled from animals before the TFPI and then at $+1,3,6,10,20,40,60,90,120,180,240$, and 420 min after. TFPI levels in plasma were measured using both immunoassay $(\bullet-\bullet)$ and bioassay $(0-0)$ (described Methods). The data for each baboon $(\mu \mathrm{g}$ TFPI/ml plasma at various sample times) were fit to a two-compartment model as described in Methods to derive half-life values. $(B)$ The pharmacokinetic data were then utilized through computer simulation to identify the necessary TFPI dosage to achieve a circulating TFPI serum concentration of $2 \mu \mathrm{g} / \mathrm{ml}$. 
Table I. Weight, Sex, E. coli Dose and Survival Times of Control and TFPI-treated Baboons at $+30 \mathrm{~min}^{*}$

\begin{tabular}{|c|c|c|c|c|}
\hline & Weight & Sex & $\begin{array}{c}\text { Mean dose } \\
\text { E. coli }\end{array}$ & Survival tim \\
\hline & $k g$ & & $C F U / \mathrm{kg} \times 10^{10}$ & $h$ \\
\hline \multicolumn{5}{|c|}{$\begin{array}{l}\text { Control } \\
\qquad \begin{array}{l}\text { (E. coli }+ \text { excipient } \\
\text { control })\end{array}\end{array}$} \\
\hline 26 & 12.1 & $\mathbf{M}$ & 5.71 & 46.0 \\
\hline 27 & 9.8 & $\mathrm{~F}$ & 5.60 & 52.5 \\
\hline 32 & 6.4 & $F$ & 5.23 & 9.7 \\
\hline 37 & 7.7 & $\mathbf{M}$ & 5.26 & 30.5 \\
\hline 41 & $\underline{5.9}$ & $\mathbf{M}$ & $\underline{5.70}$ & $\underline{60.5}$ \\
\hline Mean & $\overline{8.4}$ & & $\overline{5.5}$ & $\overline{39.9}$ \\
\hline$( \pm \mathrm{SE})$ & \pm 1.1 & & \pm 0.11 & \pm 9.0 \\
\hline \multicolumn{5}{|c|}{$\begin{array}{l}\text { Experimental } \\
\qquad(\text { E. coli }+ \text { TFPI })\end{array}$} \\
\hline 29 & 8.0 & $\mathbf{M}$ & 4.84 & $>168$ \\
\hline 30 & 7.5 & $\mathbf{M}$ & 5.22 & $>168$ \\
\hline 31 & 7.3 & $\mathbf{M}$ & 6.05 & $>168$ \\
\hline 38 & 5.2 & $\mathbf{M}$ & 6.21 & $>168$ \\
\hline 40 & $\underline{6.1}$ & $\mathbf{M}$ & $\underline{6.15}$ & $\geq 168$ \\
\hline Mean & $\overline{6.8}$ & & $\overline{5.69}$ & 168 \\
\hline$( \pm \mathrm{SE})$ & \pm 0.5 & & \pm 0.28 & \pm 0.0 \\
\hline
\end{tabular}

* TFPI administered $30 \mathrm{~min}$ after the onset of a 2-h infusion of $E$. coli.

lected physiologic parameters associated with coagulation, clinical chemistries, and the inflammatory response. Fig. 2 shows that many of the coagulation parameter changes associated with the bacterial infection were inhibited and/or attenuated in the TFPI-treated baboons. Fibrinogen levels decreased approximately $80 \%$ by $3 \mathrm{~h}$ in excipient control animals, while the TFPI-treated baboons experienced only a $20 \%$ reduction in plasma fibrinogen $(P<0.0001)$. Similarly, the increase in fibrin degradation products at 240 and $720 \mathrm{~min}$., a marker of fibrinogen consumption, was not evident in the TFPI-treated animals as compared with the controls $(P<0.05)$.

Activated partial thromboplastin time (APTT) and prothrombin time (PT) were extremely prolonged, at times beyond $4 \mathrm{~h}$ in the excipient controls (Fig. 2), probably due to the consumption of fibrinogen and other coagulation proteins. APTT increased from 37 to 208 and then to $226 \mathrm{~s}$, while PT increased from 14 to 58 , and then to $137 \mathrm{~s}$, at 4 and $12 \mathrm{~h}$, respectively. In contrast, APTT increased from 32 to 45 to $60 \mathrm{~s}$ at 4 and $12 \mathrm{~h}$, respectively, and PT increased from 15 to 18 to $22 \mathrm{~s}$ at 4 and $12 \mathrm{~h}$, respectively, in the TFPI-treated baboons ( $P$ $<0.05)$.

A gradual reduction in platelet cell concentration was noted in the excipient controls and in the TFPI-treated baboons over the 12-h observation period (Fig. 2). TFPI treatment, however, appears to retard the reduction and is most apparent at times $\geq 4 \mathrm{~h}$. The mean platelet concentration of the control group at 4,6 , and $12 \mathrm{~h}$ were $102.8 \pm 26,69 \pm 20$ and $43 \pm 5.0 \times 10^{3} / \mathrm{mm}^{3}$. In contrast, the mean platelet concentration of the TFPI-treated group at the same times were $249 \pm 44$, $236 \pm 35$, and $153 \pm 31 \times 10^{3} / \mathrm{mm}^{3}$, respectively.

Despite the lack of visible hemolysis in the TFPI-treated plasma samples, the hematocrit decreased with time and was lower at $12 \mathrm{~h}$ in the experimental (treated) group, $36 \pm 2 \%$, compared with the control group, $44 \pm 2 \%(P<0.05)$. Furthermore, the mean 7-d hematocrit value of the survivors was also low compared with base line: $28 \pm 1 \%$ vs. $42 \pm 0 \%$.

Consistent with the hematocrit results the red blood cell concentration dropped only slightly over the initial $12 \mathrm{~h}$ in both the control $\left(4.94 \pm 0.21\right.$ to $\left.4.4 \pm 0.11 \times 10^{6} / \mathrm{mm}^{3}\right)$ and TFPI-treated groups $\left(5.20 \pm 0.10\right.$ to $\left.4.88 \pm 0.17 \times 10^{6} / \mathrm{mm}^{3}\right)$, and a low $\left(3.42 \pm 0.2 \times 10^{6} / \mathrm{mm}^{3}\right)$ red cell concentration was observed in the survivors.

Leukopenia occurred to the same degree in the TFPItreated and control group, the lowest values $\left(\sim 1.48 \times 10^{3} /\right.$ $\mathrm{mm}^{3}$ ) recorded at $2 \mathrm{~h}$; however, the white blood cell concentration was found elevated at $7 \mathrm{~d}$ in the survivors with a mean of $19.2 \pm 3.5$ compared with the base line of $9.0 \pm 1.5 \times 10^{3} / \mathrm{mm}^{3}$.

Clinical responses to TFPI administration at $+30 \mathrm{~min}$. Fig. 3 shows that heart rate and respiration rate increased in both groups. Heart rate increased dramatically, from 120 beats/min to 200 beats $/ \mathrm{min}$, within the first $2 \mathrm{~h}$ of $E$. coli infusion and remained elevated during the $12 \mathrm{~h}$. Similarly, respiration rate increased after the start of the bacterial infusion and remained elevated for the $12-\mathrm{h}$ period.

Mean systolic arterial pressure (MSAP) and temperature equally declined in the TFPI treated and control groups (Fig. 3). A dramatic decrease in MSAP was observed at the end of the bacterial infusion. MSAP declined from $107 \pm 5$ to $69 \pm 5$ $\mathrm{mmHg}$ at $2 \mathrm{~h}$ and then gradually returned to $93 \pm 11 \mathrm{mmHg}$ by $10-12 \mathrm{~h}$ in the control group. Similarly, MSAP declined from $115 \pm 9$ to $74 \pm 3 \mathrm{mmHg}$ at $2 \mathrm{~h}$ and increased to $85 \pm 7 \mathrm{mmHg}$ from 6 to $12 \mathrm{~h}$. Statistically insignificant mean body temperature fluctuations were observed in the 10 baboons in response to the $E$. coli. Mean body temperature of the excipient group was $37.3 \pm 0.1^{\circ} \mathrm{C}$ at the start of the experiment and $34.7 \pm 2.2^{\circ} \mathrm{C}$ at $12 \mathrm{~h}$. Similarly, mean body temperature of the TFPI-treated animals was initially $37.0 \pm 0.3^{\circ} \mathrm{C}$ and changed minimally over $12 \mathrm{~h}$ when it was $36.9 \pm 0.2^{\circ} \mathrm{C}$.

Blood chemistries. Table II compares the statistically significant changes $(P \leq 0.05)$ in the clinical chemistries of the $E$. coli infected and treated baboons. Levels of serum creatinine, total bilirubin, uric acid, lactic acid, triglycerides, anion gap, chloride, sodium, and glucose were increased at $12 \mathrm{~h}$. The magnitude of the increases, however, was lower in the TFPI-treated animals than in the excipient controls $(P<0.05)$. Changes in the concentrations of the following parameters were observed: albumin, alkaline phosphatase, aspartate transaminase (AST), blood urea nitrogen (BUN), calcium, cholesterol, creatine kinase (CK), carbon dioxide, cortisol, potassium, lactic dehydrogenase, phosphorous, serum glutamic pyruvic transaminase (SGPT), total protein, and $\mathrm{pH}$. Their increases or decreases in concentration were not affected by the TFPI treatment ( $P$ $>0.05$ ) (data not shown). However, the mean concentrations of albumin, BUN and lactate did not return to base line values in the TFPI-treated animals (i.e., the survivors) at $7 \mathrm{~d}$. Specifically, albumin concentrations were $2.7 \pm 0.2 \mathrm{~g} / \mathrm{dl}$ at $7 \mathrm{~d}$ compared with $3.7 \pm 0.1 \mathrm{~g} / \mathrm{dl}$ at the start of the experiments. Thus albumin concentration was reduced by about $25 \%$. Similarly, serum values of BUN at $7 \mathrm{~d}$ were $13.8 \pm 2.1 \mathrm{vs.} 29.6 \pm 3.9 \mathrm{mg} / \mathrm{dl}$ at the beginning of the experiment. Finally, lactate concentrations were increased by about three-fold in the survivors. The mean base line lactate concentrations of these animals was $1.7 \pm 0.5 \mathrm{meq} /$ liter at the start of the procedure and increased to $5.7 \pm 1.2 \mathrm{meq} /$ liter at $7 \mathrm{~d}$ (Table II). 
$\%$
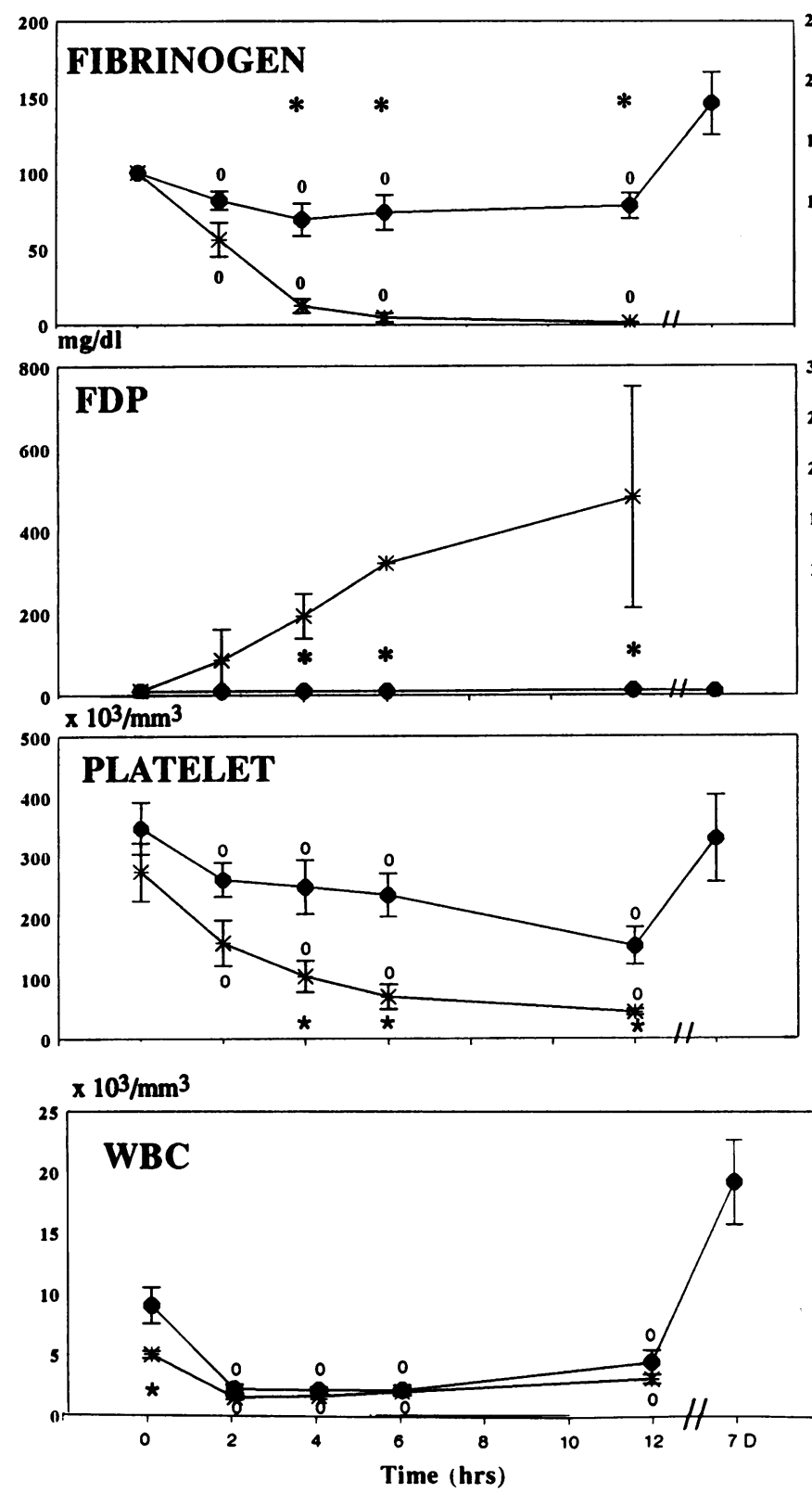

Significant Differences ( $P<.05)$ :

* Between Groups

- From T=0
Seconds
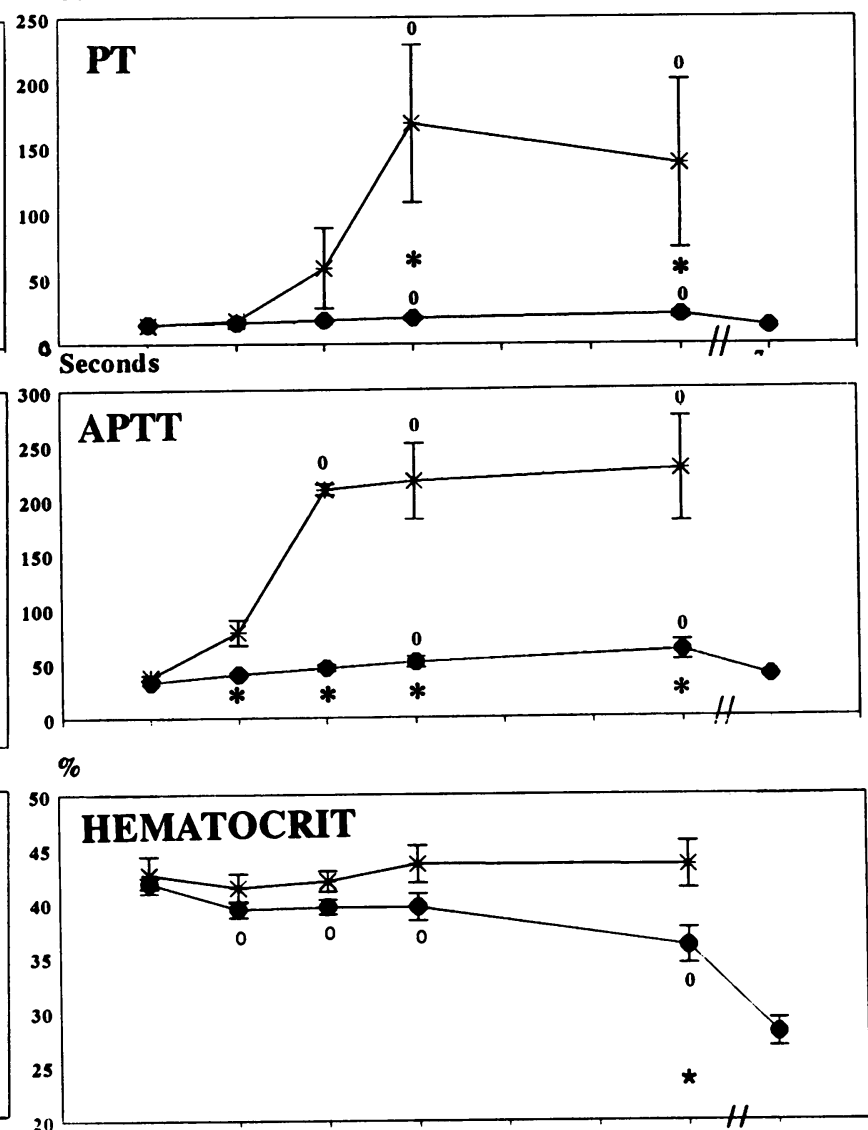

$\times 106 / \mathrm{mm}^{3}$

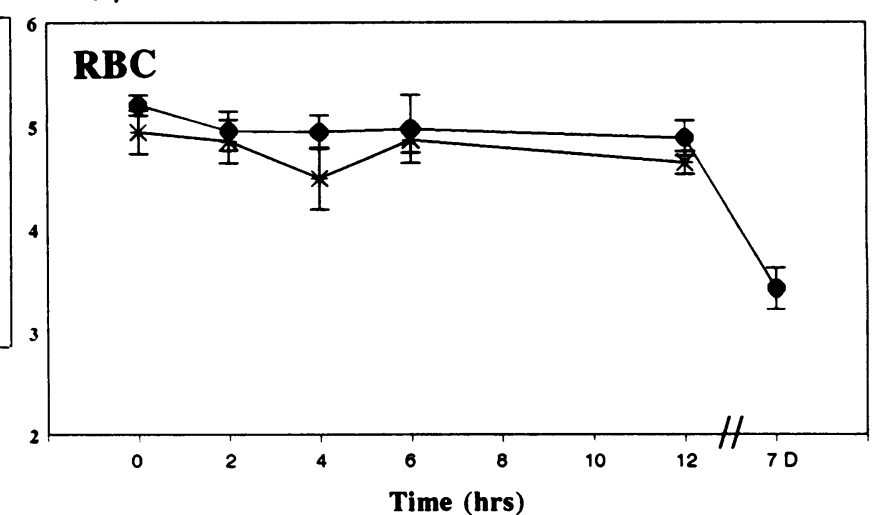

MEAN \pm SEM

* Control Treated

Figure 2. Coagulation and hematological response to TFPI administration $30 \mathrm{~min}$. after the start of a two-hour lethal bacterial intravenous infusion. Anesthetized baboons were challenged with a lethal dose of $E$. coli $\left(\sim 5 \times 10^{10}\right.$ organisms $\left./ \mathrm{kg}\right)$ intravenously infused over $2 \mathrm{~h}$. $30 \mathrm{~min}$. after the start of the bacterial infusion 5 baboons received PBS (excipient control*) and the other 5 received TFPI in PBS $(\bullet)$. Blood samples were obtained from the 10 baboons before the start of the bacterial infusion, and at 2, 4, 6, and $12 \mathrm{~h}$ after the onset of infusion. Blood samples were assayed for fibrinogen, FDP, PT, APTT, and for hematocrit, platelet, red cell and white cell counts by standard methods. Mean \pm SE of each measurement is plotted against time (h.). Statistically significant differences between groups $\left({ }^{*}\right)$ and between times $(0)$ compared with initial values are noted in the graphs.

TNF and IL-6 levels. Plasma TNF concentrations were elevated in both the excipient group and TFPI-treated baboons. Consistent with our previous studies (23), peak TNF levels were observed at $120 \mathrm{~min}$, i.e., at the end of $E$. coli infusion.
TFPI treatment did not appear to affect the rise in serum TNF concentrations or the timing of its release (Table III), suggesting that TFPI interrupts "events" downstream of the TNF response. 

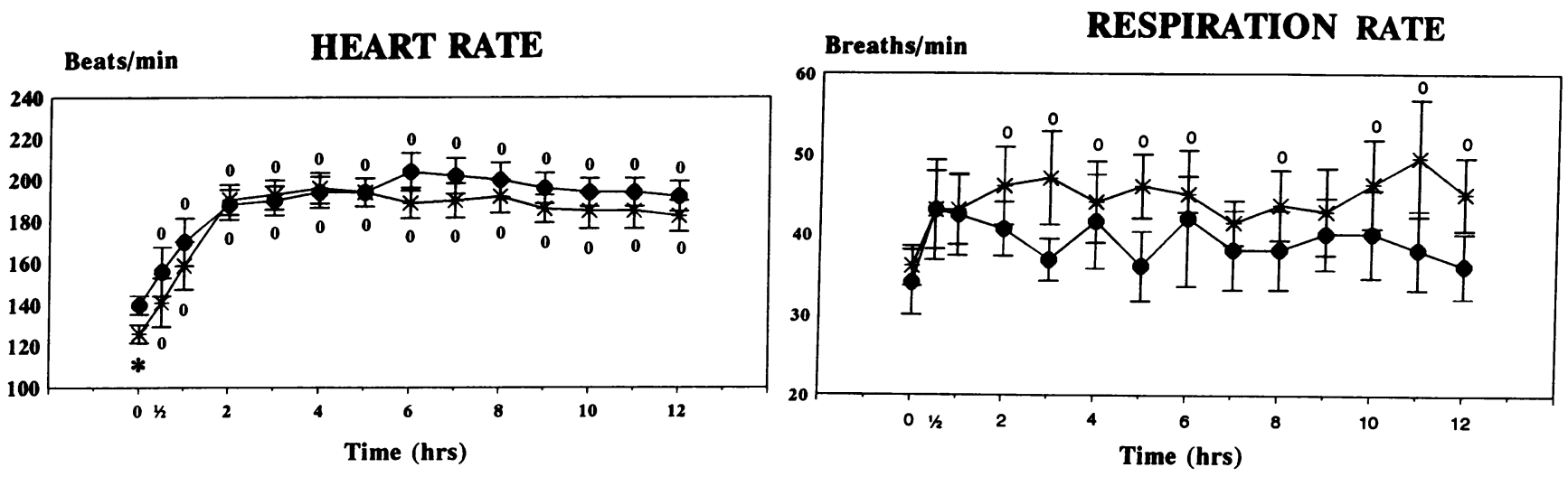

MEAN SYSTOLIC ARTERIAL PRESSURE
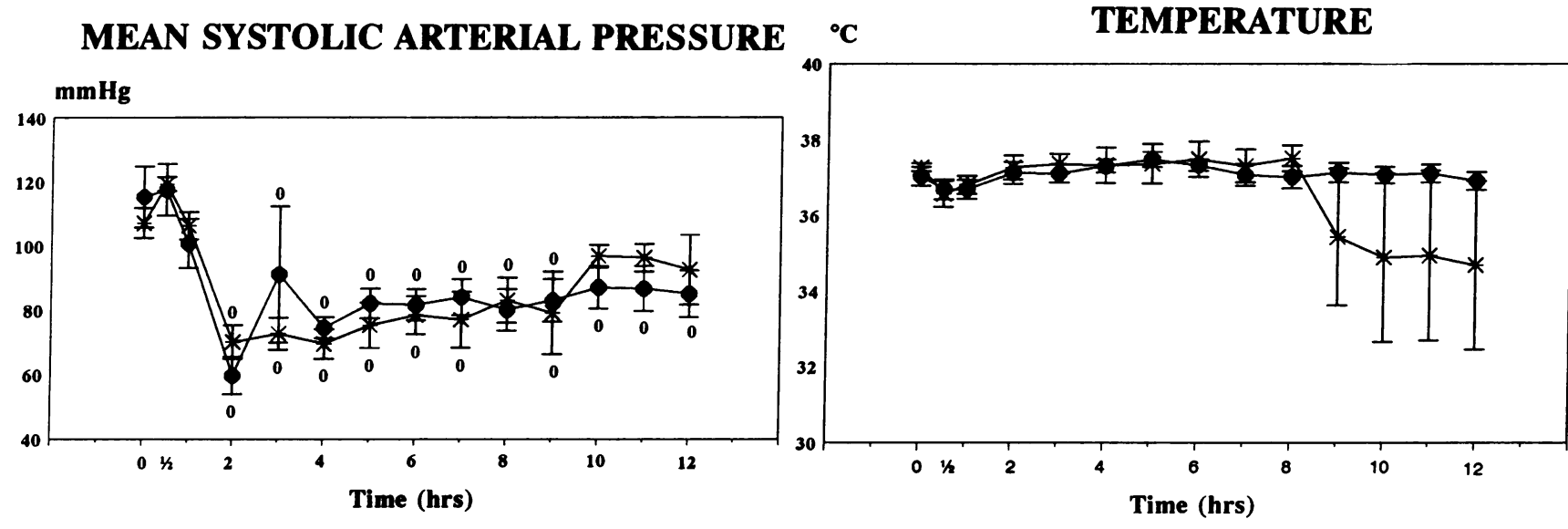

Significant Differences $(\mathrm{P}<.05)$ :
$*$ Between Groups

MEAN \pm SEM

- From $\mathrm{T}=0$

* Control - Treated

Figure 3. Clinical responses of baboons to TFPI administration $30 \mathrm{~min}$. after the start of a lethal bacterial infusion. Anesthetized baboons were challenged with a lethal dose of $E$. coli $\left(\sim 5 \times 10^{10}\right.$ organisms $\left./ \mathrm{kg}\right)$ intravenously infused over $2 \mathrm{~h} .30 \mathrm{~min}$. after the start of the infusion 5 baboons received PBS (excipient control $\left[{ }^{*}\right]$ ) and five received TFPI in PBS $(\bullet)$. Heart rate, mean systolic arterial pressure, respiration rate, and temperature were monitored before start of bacterial infusion, at the start of the infusion, half an hour later, and then hourly for $12 \mathrm{~h}$. Mean \pm SE standard error is plotted for each parameter against time $(h)$. Statistically significant changes between times $(0)$ compared with initial values are noted in the graphs.

Plasma IL- 6 concentrations also increased with time in the excipient control group, where mean IL-6 levels started at $0.03 \pm 0.01 \mathrm{pg} / \mathrm{ml}$ and rose gradually to $116 \pm 26.8 \mathrm{ng} / \mathrm{ml}$ at $4 \mathrm{~h}$ and to $211 \pm 57.5 \mathrm{ng} / \mathrm{ml}$ and $187 \pm 63.4$ at 6 and $12 \mathrm{~h}$, respectively (Table IV). Interestingly, plasma IL-6 concentrations in the TFPI-treated animals were lower than those of the control group, especially at and beyond $4 \mathrm{~h}$. Specifically, mean IL-6 concentrations started at $0.06 \pm 0.03 \mathrm{pg} / \mathrm{ml}$ and increased to $44.8 \pm 5.5 \mathrm{ng} / \mathrm{ml}$ at $4 \mathrm{~h}$. In contrast to the controls, mean IL-6 levels of the TFPI-treated baboons either remained the same $33.6 \pm 4.8 \mathrm{ng} / \mathrm{ml}$ or dropped $9.6 \pm 1.2$ at 6 and $12 \mathrm{~h}$, respectively (Table IV). IL-6 concentrations were about 20 -fold lower in the TFPI treated than in the excipient controls at $12 \mathrm{~h}(P$ $<0.05$ ).

Administration of TFPI at $+240 \mathrm{~min}$. To determine the time beyond which TFPI may no longer be effective in attenuating the $E$. coli shock, we delayed the administration of TFPI to $2 \mathrm{~h}$ after the end of the bacterial infusion. Fibrinogen consumption and the generation of fibrin degradation products were expected to be clearly evident at $4 \mathrm{~h}$. Table $\mathrm{V}$ shows that the mean $E$. coli dosage of the excipient control group in this series of experiments was $5.68( \pm 0.26) \times 10^{10} \mathrm{CFU} / \mathrm{kg}$ and the mean survival time was $28.2 \pm 9.6 \mathrm{~h}$. The mean $E$. coli dosage of the TFPI group was $5.43( \pm 0.19) \times 10^{10} \mathrm{CFU} / \mathrm{kg}$ and the mean survival time was $99 \pm 29 \mathrm{~h}$. Two of the five TFPI-treated animals were 7-d survivors. Since none of the controls survived, the $40 \%$ survival in the treated animals was significant $(P<0.05)$. There was no difference in the mean weight or $E$. coli dosage administered to each of these groups $(P>0.05)$.

Biological and biochemical effects of administration of TFPI at $+240 \mathrm{~min}$. Fig. 4 demonstrates that the administration of TFPI $2 \mathrm{~h}$ after the end of the 2-h bacterial infusion was effective in attenuating the coagulopathic response as evident by the significant decreases in fibrin-degradation products (FDP) levels, and prothrombin time at $\geq 12 \mathrm{~h}$. No significant differences in fibrinogen concentrations, APTT, and platelet cell concentration were noted at $12 \mathrm{~h}$ between the excipient control and the TFPI-treated baboons. However, fibrinogen levels at day 7 in the two animals that survived were greater than control levels; FDP, APTT, and PT values had returned 
Table II. Clinical Chemistry Summary of TFPI-treated and Control Baboons at +30 min*

\begin{tabular}{|c|c|c|c|c|c|}
\hline & \multicolumn{2}{|c|}{$\begin{array}{c}\text { Control } \\
(\mathrm{Mean} \pm \mathrm{SE})\end{array}$} & \multicolumn{3}{|c|}{$\begin{array}{c}\text { TFPI } \\
\text { (Mean } \pm \text { SE) } \\
\end{array}$} \\
\hline & T0 & $\mathrm{T}+12 \mathrm{~h}$ & T0 & $T+12 h$ & $+7 d$ \\
\hline \multicolumn{6}{|l|}{$P<0.05$} \\
\hline Creat (mg/dl) & $0.64 \pm 0.05$ & $2.68 \pm 0.27$ & $0.64 \pm 0.09$ & $0.92 \pm 0.07$ & $0.48 \pm 0.07$ \\
\hline T Bili (mg/dl) & $0.16 \pm 0.02$ & $1.35 \pm 0.33$ & $0.14 \pm 0.02$ & $0.30 \pm 0.11$ & $0.20 \pm 0.05$ \\
\hline Uric Acid (mg/dl) & $0.38 \pm 0.07$ & $0.93 \pm 0.18$ & $0.50 \pm 0.0$ & $0.50 \pm 0.00$ & $0.32 \pm 0.07$ \\
\hline Lactate (meq/liter) & $0.94 \pm 0.38$ & $6.05 \pm 0.59$ & $1.74 \pm 0.47$ & $4.10 \pm 0.34$ & $5.70 \pm 1.21$ \\
\hline Triglycerides (mg/dl) & $64 \pm 7$ & $283 \pm 19$ & $101 \pm 25$ & $161 \pm 28$ & $130 \pm 42$ \\
\hline Anion GAP (meq/liter) & $13.4 \pm 0.75$ & $19.25 \pm 0.63$ & $11.2 \pm 1.24$ & $11.25 \pm 0.25$ & $12.75 \pm 1.03$ \\
\hline $\mathrm{Cl}$ (meq/liter) & $107.68 \pm 3.73$ & $109.58 \pm 1.16$ & $105.76 \pm 0.52$ & $117.62 \pm 1.08$ & $100.56 \pm 6.61$ \\
\hline $\mathrm{Na}$ (meq/liter) & $150.58 \pm 4.81$ & $149.50 \pm 0.65$ & $146.04 \pm 1.31$ & $153.0 \pm 1.0$ & $142.26 \pm 8.51$ \\
\hline Glucose (mg/dl) & $90.00 \pm 8.17$ & $58.25 \pm 6.02$ & $109.00 \pm 14.94$ & $81.60 \pm 1.96$ & $95.20 \pm 7.33$ \\
\hline
\end{tabular}

* TFPI administered 30 min after the onset of a 2-h infusion of $E$. coli.

close to normal levels, while platelet cell concentrations were normal in one $\left(435 \times 10^{6} / \mathrm{mm}^{3}\right)$ and lower in the other $(97$ $\times 10^{6} / \mathrm{mm}^{3}$ ) (Fig. 4 ).

Although the red blood cell count and hematocrit fluctuated slightly over time in both groups during the first $12 \mathrm{~h}$, the two survivors had reduced hematocrit levels at day 7 ( 35 and $19 \%$ ) compared with the start of the procedure (43 and $41 \%$ ). Similarly, red blood cell concentration was 4.0 and 2.7 $\times 10^{6} / \mathrm{mm}^{3}$ on day 7 vs. 4.7 and $4.5 \times 10^{6} / \mathrm{mm}^{3}$ at day 0 (Fig. 4). Similar to the +30 -minute study, all the animals treated at $240 \mathrm{~min}$. experienced leukopenia, and a gradual but small increase in white blood cell (WBC) count over the $12 \mathrm{~h}$. (Fig. 4). Furthermore, the two 7-day surviving TFPI-treated baboons had elevated WBC counts $\left(12.5\right.$ and $21.8 \times 10^{3}$ cells $\left./ \mathrm{mm}^{3}\right)$ at day 7 compared with 5.1 and $8.0 \times 10^{3}$ cells $/ \mathrm{mm}^{3}$ at time zero;

Table III. Individual Animal TNF Levels (ng/ml)

\begin{tabular}{|c|c|c|c|c|}
\hline & \multicolumn{4}{|c|}{ TFPI Administration at $+30 \mathrm{~min}$} \\
\hline & T0 & +30 & +120 & +240 \\
\hline \multicolumn{5}{|c|}{$\begin{array}{l}\text { Control } \\
\qquad \begin{array}{l}\text { (E. coli }+ \text { excipient } \\
\text { control })\end{array}\end{array}$} \\
\hline 26 & $<8$ & $<8$ & 29 & $<8$ \\
\hline 27 & $<8$ & $<8$ & 41 & $<8$ \\
\hline 32 & $<8$ & $<8$ & 72 & $<8$ \\
\hline 37 & $<8$ & $<8$ & 11 & $<8$ \\
\hline 41 & $<8$ & $<8$ & 29 & $<8$ \\
\hline Mean & $<8.0$ & $<8.0$ & 36.4 & $<8.0$ \\
\hline$( \pm \mathrm{SE})$ & \pm 0.0 & \pm 0.0 & \pm 10.1 & \pm 0.0 \\
\hline \multicolumn{5}{|c|}{$\begin{array}{l}\text { Experimental } \\
\qquad(E . \text { coli }+\mathrm{TFPI})\end{array}$} \\
\hline 29 & $<8$ & $<8$ & 37 & $<8$ \\
\hline 30 & $<8$ & $<8$ & $<8$ & $<8$ \\
\hline 31 & $<8$ & $<8$ & 40 & $<8$ \\
\hline 38 & $<8$ & $<8$ & $<8$ & $<8$ \\
\hline 40 & $<8$ & $<8$ & 16 & $<8$ \\
\hline Mean & $<8$ & $<8$ & 21.8 & $<8$ \\
\hline$( \pm \mathrm{SE})$ & \pm 0.0 & \pm 0.0 & \pm 7.0 & \pm 0.0 \\
\hline
\end{tabular}

this trend is similar to that observed in the survivors among the baboons treated at $+30 \mathrm{~min}$. with TFPI. Consistent with results from the administration of TFPI at the +30 -min time period, IL-6 levels were twofold lower in the TFPI-treated baboons than in their excipient counterparts at $12 \mathrm{~h}$ (data not shown).

Clinical chemistries were measured for the 10 baboons comprising the +4-h study as we had performed for the +30 min study. We observed minimal differences between the excipient control and TFPI-treated baboons at $12 \mathrm{~h}$ (data not shown). However, consistent with the +30 -min study, lactate levels were higher in the TFPI-treated animals than in the controls $(P<0.05)$ at $12 \mathrm{~h}$ and remained elevated in the two that survived $7 \mathrm{~d}$ ( 13.2 and $4.0 \mathrm{mg} / \mathrm{dl}$ vs. 0.5 and $0.6 \mathrm{mg} / \mathrm{dl}$ at time 0 ) (data not shown). In contrast, uric acid levels were slightly lower in the TFPI-treated group than in the controls at $12 \mathrm{~h}$ and returned to normal levels in the two TFPI-treated survivors (data not shown).

Pathological results. Postmortem examinations were conducted on all baboons. Surveillance of animals was continuous for the first $36 \mathrm{~h}$; consequently tissues were removed for analysis within minutes after death, thereby avoiding postmortem autolytic changes. Lungs, liver, adrenals, kidneys, spleen, and gall bladder were target organs of the $E$. coli bacteria. Specifically, animals that received excipient $+E$. coli suffered from severe congestion, hemorrhage, fibrin deposition, edema, and massive accumulation of leukocytes in the lungs and liver, severe congestion of medullary sinusoids in the spleen, and significant evidence of tubular necrosis and thrombosis within the kidneys and severe cortical congestion in the adrenals. Organs not affected by $E$. coli were stomach, heart, pancreas, and small and large intestines. TFPI protected the liver, adrenals, kidneys, spleen, and gall bladder in which only mild to no pathology were observed. The degree of protection was slightly diminished in the lungs, in which moderate vascular congestion and mild leukocyte accumulation were observed.

\section{Discussion}

The goal of this study was to determine the efficacy of TFPI in lethal $E$. coli-induced shock. Unexpectedly, TFPI rescued $100 \%$ of the baboons given an $\mathrm{LD}_{100}$ dose of $E$. coli when administered $30 \mathrm{~min}$ after the start of the bacterial infusion, when 


\begin{tabular}{|c|c|c|c|c|c|c|}
\hline & \multicolumn{6}{|c|}{ TFPI Administration at $+30 \mathrm{~min}$} \\
\hline & T0 & +30 & +120 & +240 & +360 & +720 \\
\hline \multicolumn{7}{|c|}{$\begin{array}{l}\text { Control } \\
\qquad(E . \text { coli }+ \text { excipient control })\end{array}$} \\
\hline 26 & 0.034 & 0.027 & 21.5 & 102.3 & 347.2 & 468.5 \\
\hline 27 & 0.018 & 0.047 & 27.6 & 58.4 & 88.7 & 31.1 \\
\hline 32 & 0.010 & 0.020 & 35.6 & 217.6 & 321.7 & NT \\
\hline 37 & 0.038 & 0.048 & 36.7 & 97.6 & 196.9 & 183.2 \\
\hline 41 & 0.028 & 0.052 & 32.3 & 101.7 & 100.4 & 63.4 \\
\hline Mean \pm SE & $0.03 \pm 0.01$ & $0.04 \pm 0.01$ & $30.7 \pm 2.8$ & $116 \pm 26.8$ & $211 \pm 57.5$ & $187 \pm 63.4$ \\
\hline \multicolumn{7}{|c|}{$\begin{array}{l}\text { Experimental } \\
\qquad(E . \text { coli }+\mathrm{TFPI})\end{array}$} \\
\hline 29 & NT & NT & 30.0 & 57.3 & 50.8 & 12.5 \\
\hline 30 & 0.150 & 0.639 & 64.2 & 51.1 & 26.1 & 7.1 \\
\hline 31 & 0.013 & 0.030 & 31.8 & 48.0 & 36.7 & 10.7 \\
\hline 38 & 0.034 & 0.049 & 16.5 & 42.7 & 30.6 & 6.4 \\
\hline 40 & 0.059 & 0.058 & 17.3 & 24.8 & 23.7 & 11.3 \\
\hline Mean \pm SE & $0.06 \pm 0.03$ & $0.19 \pm 0.129$ & $32.0 \pm 8.7$ & $44.8 \pm 5.5$ & $33.6 \pm 4.8$ & $9.6 \pm 1.2$ \\
\hline
\end{tabular}

NT, not tested.

more than $1 \times 10^{10}$ organisms $/ \mathrm{kg}$ had already been introduced into the blood of the baboons. Furthermore, TFPI rescued $40 \%$ of the baboons when administered $2 \mathrm{~h}$ after the end of the bacterial infusion, i.e., when $>5 \times 10^{10}$ organisms $/ \mathrm{kg}$ had been infused and many of the baboons' host defense mechanisms had been triggered for $2 \mathrm{~h}$.

In characterization of this model, we have previously reported that within the first $30 \mathrm{~min}$ of the bacterial infusion, the

Table V. Weight, Sex, E. coli Dose and Survival Times of Control and TFPI Treated Baboons at +240 min $^{*}$

\begin{tabular}{ccccc}
\hline Weight & Sex & $\begin{array}{c}\text { Mean Dose } \\
\text { E. coli }\end{array}$ & Survival time \\
\hline$k g$ & & $C F U / \mathrm{kg} \times 10^{10}$ & $h$
\end{tabular}

Control

\begin{tabular}{lrlrr}
\multicolumn{2}{c}{$\begin{array}{c}\text { E. coli } \text { + excipient } \\
\text { control) }\end{array}$} & & & \\
33 & 6.8 & $\mathrm{M}$ & 6.22 & 63.5 \\
45 & 7.7 & $\mathrm{~F}$ & 6.29 & 18.0 \\
46 & 9.1 & $\mathrm{M}$ & 4.94 & 32.5 \\
47 & 6.6 & $\mathrm{M}$ & 5.26 & 9.0 \\
48 & $\underline{7.1}$ & $\mathrm{M}$ & $\underline{5.70}$ & $\underline{18.0}$ \\
Mean & 7.5 & & 5.68 & 28.2 \\
$( \pm$ SE) & \pm 0.5 & & \pm 0.26 & \pm 9.6
\end{tabular}

Experimental

$$
\text { (E. coli }+ \text { TFPI) }
$$

$\begin{array}{lrlrr}34 & 5.2 & \mathrm{M} & 5.65 & 58 \\ 35 & 7.3 & \mathrm{M} & 5.62 & >168 \\ 36 & 6.8 & \mathrm{M} & 4.84 & >168 \\ 44 & 9.1 & \mathrm{M} & 5.87 & 69 \\ 49 & \underline{7.5} & \mathrm{~F} & \underline{5.17} & \underline{35} \\ \text { Mean } & 7.2 & & 5.43 & 99.6 \\ ( \pm \text { SE) } & \pm 0.6 & & \pm 0.19 & \pm 28.5\end{array}$

* 240 min after the onset of a 2-h infusion of E. coli.
PMN leukocyte concentration in circulating blood declined sharply (26), thrombin-antithrombin (TAT) complexes, tissue plasminogen activator/plasminogen activator inhibitor $(t-$ PA/PAI) and plasmin anti-plasmin (PAP) complexes started to appear (27), and the activation of the complement cascade in lethal $E$. coli challenge was clearly evident (De Boer, J. P., Creasey, A. A., Chang, A., Roem, D., Eerenberg, A. J. M., Hack, C. E., and Taylor, F. B., Jr., manuscript submitted for publication). Furthermore we found that TNF levels peak at the end of the $E$. coli infusion, i.e., at $2 \mathrm{~h}$, when IL- $1 \beta$ and IL-6 start to achieve measurable levels (23); the decline in fibrinogen levels and generation of fibrin degradation products were apparent between 3 and $4 \mathrm{~h}$ (27).

TFPI administration to the $E$. coli infected baboons resulted in highly significant biochemical changes that appear to correlate with the increased survival; first, TFPI prevented, retarded, and even reversed fibrinogen consumption when administered as late as $4 \mathrm{~h}$ after the start of a lethal bacterial infusion; second, TFPI attenuated/blunted the dramatic increase in IL- 6 levels, frequently observed in the untreated animals (23); third, TFPI diminished the level of markers of cell injury (creatinine, uric acid, lactic acid) as well as the metabolic acidosis (anion gap, chloride, and sodium) that were evident in the controls.

Consistent with the decreased serum levels of many markers of hypoxia, acidosis, and cell injury, TFPI afforded remarkable morphological protection to the kidneys, adrenals, liver, spleen, and the lungs from pathological changes. Specifically, TFPI treatment resulted in the prevention of tubular necrosis and glomerular thrombosis in the kidneys; cortical congestion, hemorrhage, necrosis, and leukocyte accumulation in the adrenals; prevention of vascular congestion and accumulation of leukocytes in the liver; prevention of medullary congestion, hemorrhage, and necrosis in the spleen; and fibrin thrombi deposition and edema formation in the lungs. TFPI significantly attenuated leukocyte influx and vascular congestion in the lungs. The two baboons that received TFPI at $4 \mathrm{~h}$ 


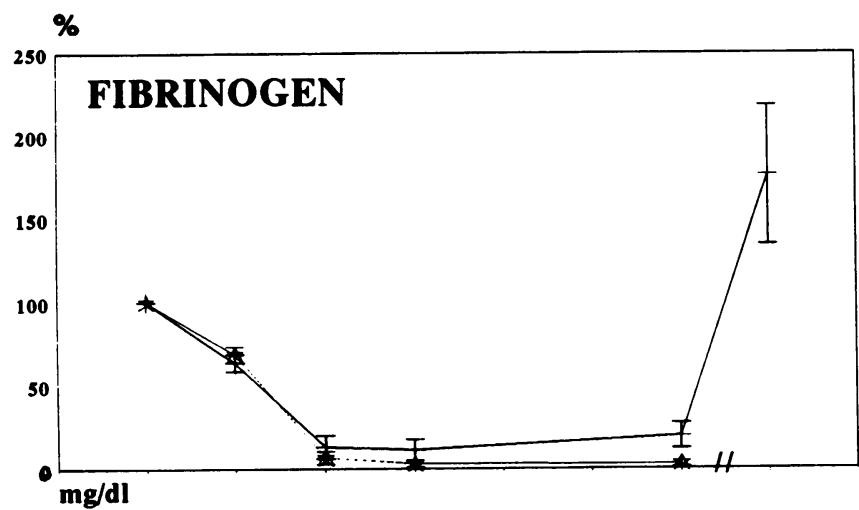

Seconds
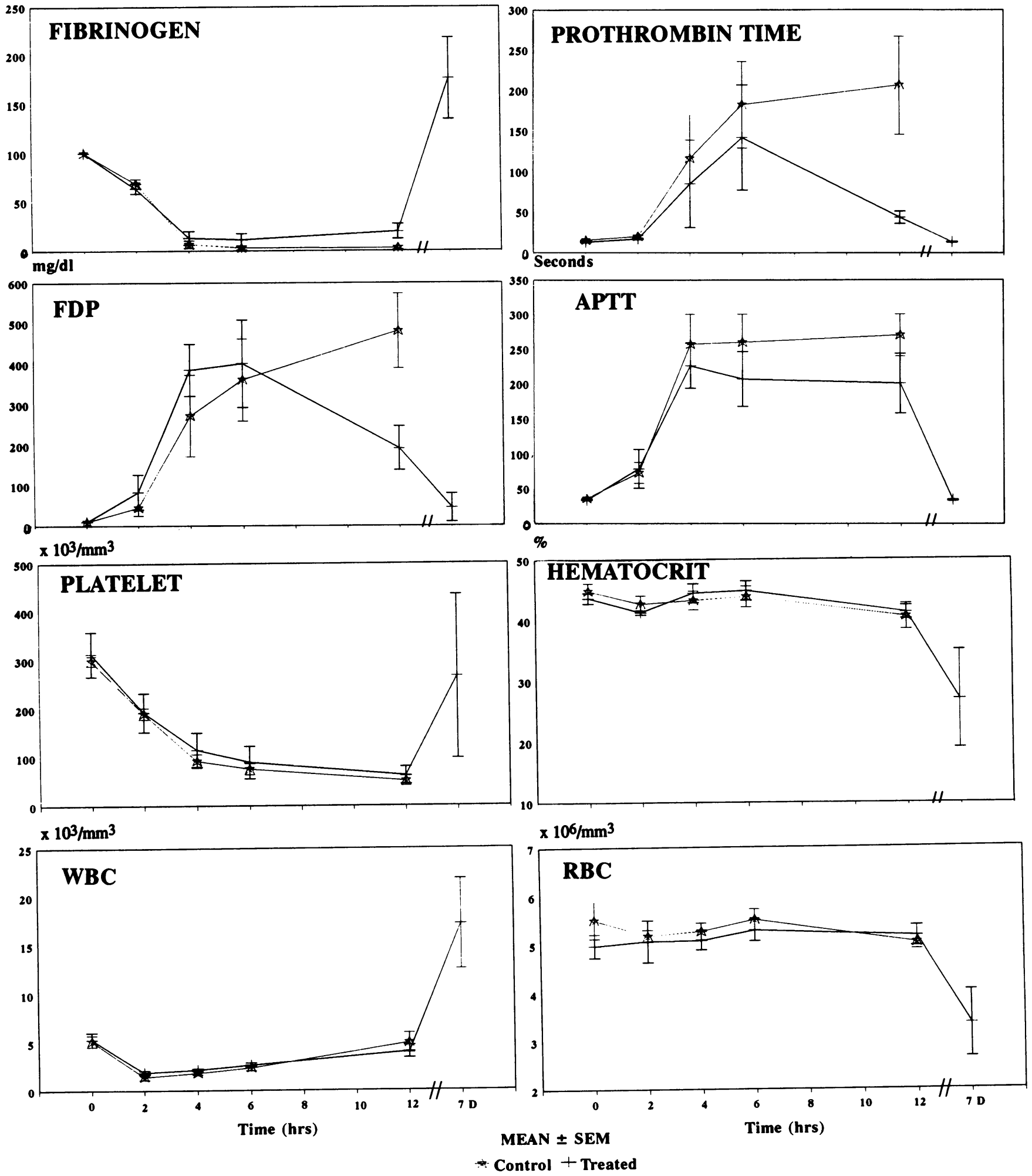

$\times 106 / \mathrm{mm}^{3}$

Figure 4. Coagulation and hematological responses to TFPI administration $4 \mathrm{~h}$ after the start of lethal bacterial infusion. Anesthetized baboons received a lethal $E$. coli infusion over $2 \mathrm{~h} .4 \mathrm{~h}$ after the start of the bacterial infusion 5 baboons received PBS excipient control (*) and 5 received TFPI ( +). Blood samples were collected before start of bacterial infusion and at $0,2,4,6,12 \mathrm{~h}$ and at $7 \mathrm{~d}$ (in survivors). Means \pm SE for the following parameters are plotted against time: fibrinogen, FDP, prothrombin time, activated APTT, hematocrit, platelet, red blood cell, and white blood cell counts. 
and survived $7 \mathrm{~d}$ showed a very similar prevention of pathological changes as those described above. However, there was some mild edema and fibrin present in alveolar sacs of the lungs with moderate leukocyte accumulation and vascular congestion. There was no evidence of multiple organ failure in any of the TFPI-treated baboons that survived $7 \mathrm{~d}$. This degree of protection is remarkable and unexpected given the delayed administration of TFPI and the massive bacterial challenge afforded to the baboons.

The TFPI-treated baboons that survived $7 \mathrm{~d}$ exhibited a decreased red blood cell concentration and an increase in leukocyte number. Histological examination did not reveal the occurrence of hemorrhage in any tissue. Thus the lower hematocrit may be attributed either to hemodilution or to a slow generation of erythrocytes in the bone marrow as an outcome of the experimental procedure. 7-d survivors of other therapy modalities in the same model appear to suffer from similar hematological abnormalities (L.B. Hinshaw, unpublished results). This suggests that these hematological changes are not caused directly by TFPI. However, TFPI toxicology studies with uninfected baboons are best to ultimately resolve this matter. Similarly, the cause for the increase in leukocyte concentration at $7 \mathrm{~d}$ was not clear since none of the baboons showed any evidence of infection. The leukocytosis may be an indirect effect of TFPI or a delayed host response to the infection.

Previous studies using antibodies to TFPI have demonstrated its physiologic relevance, especially when small amounts of tissue factor were administered (9). Our results in the baboons confirm these earlier observations, underscore the importance of TFPI in preventing the tissue factor or Xa-associated processes, and suggest yet a new role for TFPI, which includes a possible systemic antiinflammatory effect on cells including monocytes, macrophages, and endothelial cells as reflected by the attenuation of the IL- 6 response in the TFPItreated baboons.

Studies have been performed with various anticoagulants in baboons challenged with lethal $E$. coli. Antibodies to tissue factor infused before the bacterial challenge were reported to attenuate the coagulopathic response and degree of cardiovascular collapse and to improve survival (10). Similar to the tissue factor antibodies, TFPI attenuated the coagulopathic response but did not affect the degree of cardiovascular collapse (MSAP) during the 12-h procedure, and yet improved the survival of the baboons. This may be due to the fact that the former were given before the bacterial challenge, and the latter was given during or after the bacterial infusion. In principle the antibodies to tissue factor and TFPI were targeted to bind and neutralize tissue factor function, the mechanisms by which these two compounds operate are different: antibodies to tissue factor bind to tissue factor and neutralize its function (10). TFPI binds to Factor Xa directly and neutralizes its activity; in addition it inhibits tissue factor activity by formation of a Factor VIIa/tissue factor/Factor $\mathrm{Xa} / \mathrm{Ca}^{++}$complex. These differences may also account for the differing effects.

Activated protein $\mathrm{C}$, anti-thrombin III, but not active-siteinhibited Xa (DEGR-Xa), protect baboons from lethal $E$. coli (28-30). The administration of native-activated protein $C$ before intravenous administration of bacteria and thereafter was regulated by preventing fibrinogen levels from diminishing below $70 \%$. Using this regimen, activated protein $C$ prevented the reduction in MSAP and attenuated the cell injury as reflected by serum glutamic pyruvic transaminase (SGPT) levels, which remained within the normal range. There was, however, a decline in platelet concentration to $50 \%$ of control at $6 \mathrm{~h}$. Infusion of antithrombin III together with $E$. coli limited the reduction of blood pressure and fibrinogen and the increase of creatinine phosphokinase (CPK) (29). In order to protect baboons from lethal $E$. coli, antithrombin III levels had to be at $\geq 6 \mathrm{U} / \mathrm{ml}$ by the first hour of the experiment. Preloading the animals with large amounts of antithrombin III an hour before bacterial challenge gave the best protection.

In contrast to results with a variety of anticoagulants described above, pretreatment of baboons with DEGR-Xa before infusion of $E$. coli blocked fibrinogen and Factor $\mathrm{V}$ consumption, but did not prevent the decrease in blood pressure, organ damage, or ultimate lethal effects of the bacterial infusion (30). These results suggest that either the DEGR-Xa antagonist was not a sufficiently potent anticoagulant or the coagulant response did not contribute to lethality in this model. If the latter premise is correct, then it is difficult to explain the protection conferred onto the baboons by TFPI in this study, unless the observed influences of TFPI on the noncoagulation-associated processes exemplified by the dramatic decrease in IL-6 levels were important for survival. Interestingly, a recent study in endotoxin-treated mice reported that the relative disappearance of IL-6 after $10 \mathrm{~h}$ in mice receiving nonlethal doses of LPS corresponded with their symptomatic recovery and that IL-6 may be a more realistic marker of impending lethality than TNF in cases of endotoxic shock (31).

Additionally, recent reports suggest possible close interactions between the coagulation cascade and the inflammatory response (32). The decreased IL-6 levels observed in the $E$. coli-challenged and TFPI-treated baboons in the present study support this hypothesis. It is suggested that in addition to its anticoagulant activity, a physiologic role of TFPI may involve the modulation of the interaction of the coagulation pathway with various participants of the immune system; however, further studies are required to examine this hypothesis.

\section{Acknowledgments}

The authors thank Glenn Peer and Robert Xue for assistance with the E. coli baboon model and outstanding technical support; Dr. Stanley Kosanke for the histopathology; Clay, Alia, and Amanda Creasey for their encouragement and support; Gerald Galluppi for helpful discussions and encouragement; John Young, Bob Bauer, and Chyung Cook for pharmacokinetic consultation; Helen Chin for preparation of the manuscript; and Janet Rose and Sach Lai for IL-6 and TNF assays.

\section{References}

1. Müller-Berghaus, G. 1989. Pathophysiologic and biochemical events in disseminated intravascular coagulation: dysregulation of procoagulant and anticoagulant pathways. Semin. Thromb. Hemostasis. 15:58-87.

2. Marder, V. J. 1983. Consumptive thrombohemorrhagic disorders. In: Hematology. W. J. Williams, E. Beutler, A. J. Erslev, and M. A. Lichtman, editors McGraw-Hill Book Company, New York. 1433-1461.

3. Rivers, R. P. A., W. E. Hathaway, and W. L. Weston. 1975. The endotoxin induced coagulant activity of human monocytes. Br. J. Haematol. 30:311-316.

4. Colucci, M., R. Balconi, A. Lorenzet, A. Pietra, D. Locati, M. B. Donati, and N. Semararo. 1983. Cultured human endothelial cells generate tissue factor in response to endotoxin. J. Clin. Invest. 71:1893-1896.

5. Lyberg, T., S. A. Galdal, S. A. Evansen, and H. Prydz. 1983. Cellular cooperation in endothelial cell thromboplastin synthesis. Br. J. Haematol. 53:8595.

6. Nawroth, P. P., D. A. Handley, C. T. Esmon, and D. M. Stern. 1986. Interleukin-1 induces endothelial cell procoagulant while suppressing cell-surface anticoagulant activity. Proc. Natl. Acad. Sci. USA. 83:3460-3464. 
7. Bevilacqua, M. P., J. S. Pober, G. R. Majeau, W. Fiers, R. S. Cotran, and M. A. Gimbrone. 1986. Recombinant tumor necrosis factor induces procoagulant activity in cultured human vascular endothelium. Characterization and comparison with the actions of interleukin-1. Proc. Natl. Acad. Sci. USA. 83:45334537.

8. Osterud, B., and T. Flaegstad. 1983. Increased thromboplastin activity in monocytes of patients with meningococcal infection: related to an unfavorable prognosis. Thromb. Haemostasis. 49:5-7.

9. Warr, T. A., L. Vijaya Mohan Rao, and S. Rapaport. 1990. Disseminated intravascular coagulation in rabbits induced by administration of endotoxin or tissue factor: effect of antitissue factor antibodies and measurement of plasma extrinsic pathway inhibitor activity. Blood. 75:1481-1489.

10. Taylor, F. B., Jr., A. Chang, W. Ruf, J. H. Morrissey, L. Hinshaw, R. Catlett, K. Blick, and T. S. Edgington. 1991. Lethal E. coli septic shock is prevented by blocking tissue factor with monoclonal antibody. Circ. Shock. 33:127135.

11. Girard, T. J., L. A. Warren, W. F. Novotny, K. Likert, S. G. Brown, J. P. Miletich, and G. J. Broze, Jr. 1989. Functional significance of the Kunitz-type inhibitory domains of lipoprotein-associated coagulation inhibitor. Nature (Lond.). 338:518-520.

12. Rapaport, S. I. 1991. The extrinsic pathway inhibitor: a regulator of tissue factor-dependent blood coagulation. Thromb. Haemostasis. 66:6-15.

13. Sandset, P. M., B. J. Warn-Cramer, L. Vijaya Mohan Rao, S. L. Maki, and S. I. Rapaport. 1991. Depletion of extrinsic pathway inhibitor (EPI) sensitizes rabbits to disseminated intravascular coagulation induced with tissue factor: evidence supporting a physiologic role for EPI as a natural anticoagulant. Proc. Natl. Acad. Sci. USA. 88:708-712.

14. Day, K. C., L. C. Hoffman, M. O. Palmier, K. K. Kretzmer, M. D. Huang, E. Y. Pyla, E. Spokas, G. J. Broze, Jr., T. G. Warren, and T-C. Wün. 1990. Recombinant lipoprotein-associated coagulation inhibitor inhibits tissue thromboplastin-induced intravascular coagulation in the rabbit. Blood. 76:1538-1545.

15. Bajaj, M. S., M. N. Kuppuswamy, H. Saito, S. G. Spitzer, and S. P. Bajaj. 1990. Cultured normal human hepatocytes do not synthesize lipoprotein-associated coagulation inhibitor. Evidence that endothelium is the principal site of its synthesis. Proc. Natl. Acad. Sci. USA. 87:8869-8873.

16. Ameri, A., M. N. Kuppuswamy, S. Basu, and S. P. Bajaj. 1992. Expression of tissue factor pathway inhibitor by cultured endothelial cells in response to inflammatory mediators. Blood. 79:3219-3226.

17. Sandset, P. M., O. Roise, A. O. Aasen, and U. Abildgaard. 1989. Extrinsic pathway inhibitor in post-operative / post-traumatic septicemia: increased levels in fatal cases. Haemostasis. 19:189-195.

18. Novotny, W. F., S. G. Brown, J. P. Miletich, D. J. Rader, and G. J. Broze, Jr. 1991. Plasma antigen levels of the lipoprotein-associated coagulation inhibitor in patient samples. Blood. 78:387-393.

19. Wun, T-C., K. K. Kretzmer, M. D. Palmier, K. C. Day, M. D. Huang D. J. Welsch, C. Lewis, R. A. Wolfe, J. F. Zobel, G. W. Lange, et al. 1992.
Comparison of recombinant tissue factor pathway inhibitors expressed in human SK hepatoma, mouse $\mathrm{C} 127$, baby hamster kidney, and chinese hamster ovary cells. Thromb. Haemostasis. 68:54-59.

20. Hinshaw, L. B., D. J. Brackett, L. T. Archer, B. K. Beller, and M. F. Wilson. 1982. Detection of the "hyperdynamic state" of sepsis in the baboon during lethal $E$. coli infusion. J. Trauma. 23:361-365.

21. Hinshaw, L. B., L. T. Archer, B. K. Beller-Todd, J. J. Coalson, D. J. Flournoy, R. Passey, B. Benjamin, and G. L. White. 1989. Survival of primates in $\mathrm{LD}_{100}$ septic shock following steroid/antibiotic therapy. J. Surg. Res. 28:151170.

22. Friberger, P, L. Sorskog, K. Nilsson, and M. Knos. 1987. The use of a quantitative assay in endotoxing testing. Prog. Clin. Biol. Res. 231:149-169.

23. Creasey, A. A., P. Stevens, J. Kenney, A. C. Allison, K. Warren, R. Catlett, L. Hinshaw, and F. B. Taylor, Jr. 1991. Endotoxin and cytokine profile in plasma of baboons challenged with lethal and sublethal $E$. coli. Circ. Shock. 33:84-91.

24. Palmier, M. O., L. J. Hall, C. M. Reisch, M. K. Baldwin, A. G. E. Wilson, and T-C. Wün. 1992. Clearance of recombinant tissue factor pathway inhibitor (TFPI) in rabbits. Thromb. Haemostasis. 68:33-36.

25. Novotny, W. F., T. J. Girard, J. P. Miletich, and G. J. Broze, Jr. 1989. Purification and characterization of the lipoprotein associated coagulation inhibitor from human plasma. J. Biol. Chem. 264:18832-18837.

26. Taylor, F. B. Jr. 1991. Baboon model of E. coli sepsis: Summary of staging, mechanism and diagnostic markers. In Colloquium Mosbach Molecular Aspects of Inflammation. H. Sies, L. Flohe, and G. Zimmer, editors. Springer Verlag, Berlin/Heidelberg, Germany. 277-288.

27. De Boer, J. P., A. A. Creasey, A. Chang, D. Roem, M. C. Brouwer, A. J. M. Eerenberg, C. E. Hack, and F. B. Taylor, Jr. 1992. Activation patterns of coagulation and fibrinolysis in baboons following infusion with lethal or sublethal dose of E. coli. Circ. Shock. 39:59-67.

28. Taylor, F. B., Jr., A. Chang, C. T. Esmon, A. D'Angelo, S. Vigano-D'Angelo, and K. E. Blick. 1987. Protein C prevents the coagulopathic and lethal effects of Escherichia coli infusion in the baboon. J. Clin. Invest. 79:918-925.

29. Taylor, F. B., Jr., T. E. Emerson, Jr., R. Jordan, A. K. Chang, and K. E. Blick. 1988. Antithrombin-III prevents the lethal effects of Escherichia coli infusion in baboons. Circ. Shock. 26:227-235.

30. Taylor, F. B., Jr., A. C. K. Chang, G. T. Peer, T. Mather, K. Blick, R. Catlett, M. Lockhart, and C. T. Esmon. 1991. DEGR-Factor Xa blocks disseminated intravascular coagulation initiated by Escherichia coli without preventing shock or organ damage. Blood. 78:364-368.

31. Kelly, N. M., and A. Cross. 1992. Interleukin-6 is a better marker of lethality than tumor necrosis factor in endotoxin treated mice. FEMS (Fed. Eur. Microbiol. Soc.) Microbiol. Immunol. 89:317-322.

32. Cohen, W. M., H. F. Wu, G. L. Featherstone, J. W. Jenzano, and R. L. Lundblad. 1991. Linkage between blood coagulation and inflammation: Stimulation of neutrophil tissue kallikrein by thrombin. Biochem. Biophys. Res. Commun. 176:315-320. 